\title{
Engineering Master Students ' Views on Digital Entrepreneurship in a Host European Country
}

\author{
Andreas Ahrens \\ Department of Electrical \\ Engineering and Computer Science, \\ Hochschule Wismar, University of \\ Technology, Business and Design \\ Wismar, Germany \\ andreas.ahrens@hs-wismar.de \\ Mihails Zascerinskis \\ Rezekne Academy of Technologies \\ Riga, Latvia \\ mihails.zascerinskis@gmail.com
}

\author{
Parulkumari P Bhati \\ Department of Mathematics \& \\ Humanities Nirma University \\ Ahmedabad, India \\ dr.parulbhati@gmail.com
}

Anastasija Aleksejeva

Rezekne Academy of Technologies

Riga, Latvia

vaset@inbox.lv

\author{
Jelena Zascerinska \\ Centre for Education and Innovation \\ Research \\ Riga, Latvia \\ knezna@inbox.lv
}

\author{
Irina Abjalkiene \\ Rezekne Academy of Technologies \\ Riga, Latvia \\ irinaabjalkiene@inbox.lv
}

\begin{abstract}
The importance of engineering education in promoting engineering students' entrepreneurial attitudes and behaviours now is widely recognised. The aim of the research is to explore international engineering Master students' views on digital entrepreneurship in a host European country underpinning the elaboration of implications for engineering education in a host country. The research methods imply the use of both - theoretical and empirical - methods. Theoretical methods included analysis of scientific literature, theoretical modelling, systematisation, synthesis, comparison, generalisation. The empirical study was carried out in Germany in February 2021. 32 engineering Master students took part in the online survey. The online survey was based on the online questionnaire. The obtained data were described with the use of percentage, standard deviation and weighted average. The data description was followed by data interpretation and summarization. The use of the theoretical methods allows identifying that digital entrepreneurship is a supplement to traditional settings entrepreneurship proceeds in. The theoretical research resulted in the conceptual framework built of engineering student's intention to become a digital entrepreneur, the use of the host country language, the use of engineering knowledge in digital entrepreneurship. The results of the empirical study allow finding out that the engineering Master students' view digital entrepreneurship in a positive way. The survey results show that the engineering students focus their digital entrepreneurship on their professional field, namely engineering. The survey also outlined two major factors, namely host country language and host country rules, that limit the opportunities of
\end{abstract}

becoming a digital entrepreneur in a host country. The implications for engineering education, that international engineering Master students receive in a host country, imply the integration of entrepreneurial culture, namely host country language and host country rules, into engineering education in a host country. The emphasis of the host country language and host country rules should be placed on their use for entrepreneurial purposes. By the entrepreneurial purposes, specific activities that are tied to entrepreneurship are meant. Training of host country language and host country rules within engineering education should be centred on their use for entrepreneurship.

Keywords - Digital entrepreneurship, engineering students, host country, master studies.

\section{INTRODUCTION}

Engineering education has always been in the locus of the research community due to its significant role in promoting the engineers' and prospective engineers' skills necessary for finding innovative solutions in respond to pressing environmental, social and other challenges. Therefore, engineering education conventionally focuses on innovation creation and management. It should be noted that "innovation is the specific instrument of entrepreneurship, the act that endows resources with a new capacity to create wealth" [1]. It should be also stressed that entrepreneurship is a fundamental economic resource or factor of production [2]. Entrepreneurship being an 
economic resource influences the development of regional economics. Entrepreneurship in regional economics is often revealed by teaching international Master students at local universities [3].

Innovation in the absence of entrepreneurship generally yields nominal restricted economic impact [4]. It is the entrepreneurial spirit that paves the way to continued economic growth by using the multi-dimensional aspects of innovation [4]. Figure 1 illustrates the relationships between the development of regional economy, engineering education and innovation. It should be highlighted that entrepreneurship may be restricted to a place while innovation is dynamic and portable [4]. The development of digital technologies motivates new innovations through technology transfer [5].

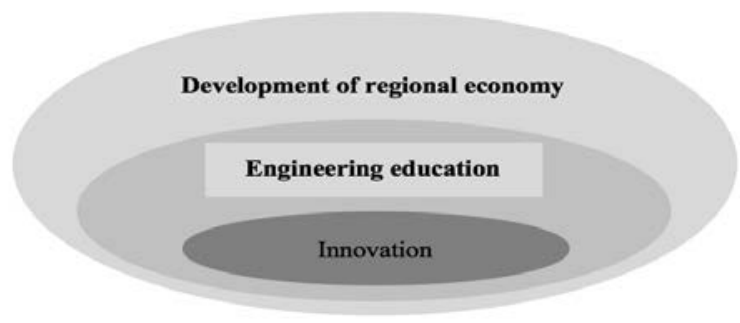

Fig. 1. The relationships between the development of regional economy, engineering education and innovation.

This relationship between innovation and entrepreneurship as shown in Figure 2 leads to the incorporation of entrepreneurship education into engineering studies [6], [7].

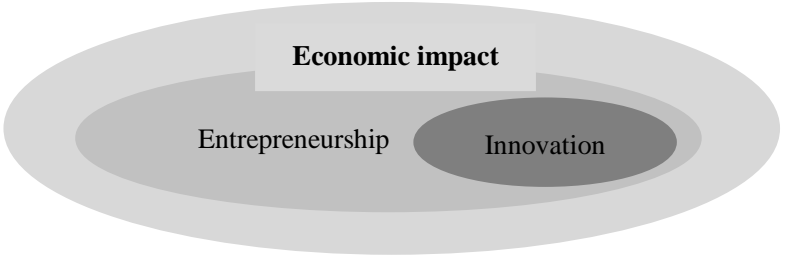

Fig. 2. The relationships between the economic impact, entrepreneruship and innovation.

A positive effect of entrepreneurship education on engineering students' entrepreneurial intentions [8], [7] as well as knowledge, skills and attitude to run their own business and/or enterprise [6] has been revealed.

Along with the development of digital technologies, digital entrepreneurship has attracted more attention from researchers and educators worldwide. Engineering students were introduced to Enterprise 2.0 and 3.0 [9] as well as e-Business applications [10]. It should be pointed that the COVID-19 pandemic significantly influenced the fast growth of digital entrepreneurship in the world. Extreme events such as the COVID-19 pandemic change the framework conditions and thus create new entrepreneurial opportunities and change risk perception because the risk of alternative activities changes [11]. Against this background, immigrants, including engineering students with migrant background, who are engaging in digital entrepreneurship have been neglected in current related literature [12].

Analysis of scientific literature allows finding out that immigrant entrepreneurship has played a critical role in the socio-economic development of most advanced countries from the 1970s [13]. Regional economic benefit from the entrepreneurs with migrant background, in terms of improvement of opportunities in the economic, social and civic life of their new country [14]. The previous research discovered that employment of immigrants, who communicate in a language of the country local companies do business with is proposed to be beneficial for all the stakeholders, namely host country' companies, partners of host country' companies, and the employed immigrants [15]. The impact of immigrants' home-country entrepreneurial ecosystem (EE) factors on transnational immigrant entrepreneurs (TIEs) has been investigated [16], too.

As the importance of engineering education in promoting engineering students' entrepreneurial attitudes and behaviours now is widely recognised, the enabling research question is: What are engineering Master students' views on digital entrepreneurship in a host European country?

The aim of the research is to explore international engineering Master students' views on digital entrepreneurship in a host European country underpinning the elaboration of implications for engineering education in a host country.

\section{CONCEPTUAL FRAMEWORK}

The conceptual framework of the present work is shaped by the implementation of theoretical methods such as

- Analysis of scientific literature,

- Theoretical modelling,

- Systematisation,

- Synthesis,

- Comparison,

- Generalisation.

Digital entrepreneurship embraces all new ventures and the transformation of existing businesses that drive economic and/or social value by creating and using novel digital technologies [17]. The authors support the view that digital entrepreneurship is a supplement or complement to traditional settings [18] as depicted in Figure 3.

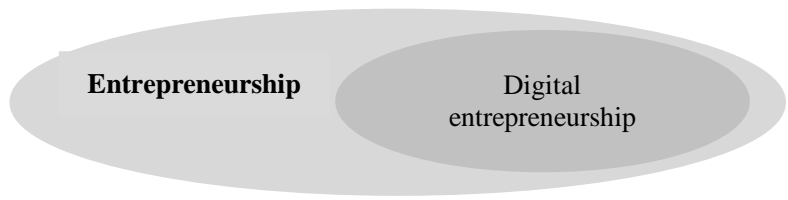

Fig. 3. The relationships between entrepreneurship and digital entrepreneruship. 
In turn, the theoretical framework of immigrants and asylum seekers' digital entrepreneurship competence created for training purposes includes [18]

1. The opportunity competencies that are related to identifying, assessing and seeking market opportunities: identification and definition of a viable market niche; development of products/services appropriate to chosen market niche/innovation; idea generation; environmental scanning; recognising and envisioning taking advantage of opportunities; formulating strategies for taking advantage of opportunities.

2. The organizing competencies that are related to managerial functions such as planning, organizing, leading and controlling: development of the management system necessary for long-term functioning of the organisation; acquisition and development of resources required; business operational skills; involvement with start-ups; financial and budgeting skills; management style; marketing skills; industry skills; the ability to implement strategy (develop programmes, budgets, procedures, evaluate performance); market analysis skills; business plan preparation skills; goal setting skills.

3. The relationship competencies that embrace the ability to build, keep and use networks with stakeholders: development of organisational culture management system; delegation skills; collaboration skills; the ability to motivate others (individuals and groups); personnel management skills; human relation skills; leadership skills.

4. The conceptual competencies that refer to creative thinking, innovative behaviour, assessment of risk, etc.: creative thinking; innovativeness; organisational skills; interpersonal skills; emotional intelligence; the ability to manage customers; coordination skills; written communication skills; oral communication skills; decision making skills; analytical skills; logical thinking; critical thinking; deal-making skills.

5. The strategic competencies that deal with setting, evaluating, and implementing strategies of a venture: strategic management skills; vision and goals setting skills; research and analysis skills; data management; decision making skills; developing of the monitoring systems; quality assessment skills.

6. The commitment competencies that are the abilities that drive the entrepreneur to work hard and face the difficulties involved in sustaining the business: sustainable leadership skills; team building; coaching and mentoring; personal development; commitment to excellence; persuasive techniques; trustworthiness; change management.

7. The digital-based entrepreneurship competencies: using the potential of network - based business; care about technological developments and market dynamics; maximum use of information technologies and supply management improvement; innovation management and implementation.

Digital entrepreneurship as well as students' digital entrepreneurship are formed in a socio-cultural environment [19] as shown in Figure 4.

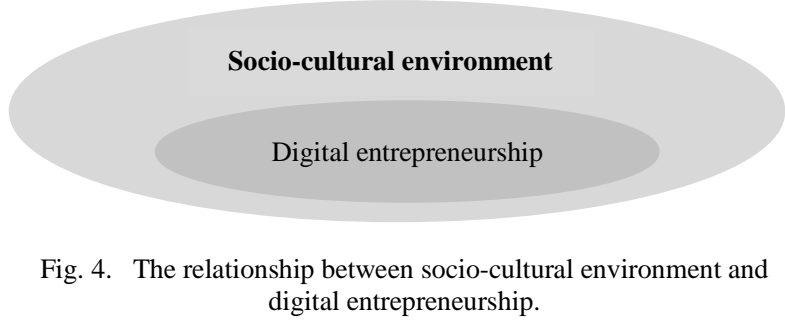

Socio-cultural environment is life, our real, subjective, everyday life [20]. Socio-cultural environment is mediated through culture and language.

Training of migrants who expressed their intention to become an entrepreneur often faces the issues of [15], [21] $-[22]$

- Use of the host country language as the language of instruction,

- Migrants' busy lifestyle in the host country,

- A different level of entrepreneurial skills,

- Required resources.

Hence, before the training, training participants' views have to be analysed. View is identified as individual's opinion based on his/her knowledge, skills and attitudes to a phenomenon [23].

It should be emphasized that university teachers are also training participants. Their view on training of engineering Master students was presented in the theoretical framework on master programme for international students [24]. One of the key concepts in the framework was students' language proficiency and problems. The authors propose that students' language proficiency and problems should be considered from the perspective of the unity of all the student's language, namely mother tongue, second language, foreign language, host country language, etc [25] within International Master studies. Often master programmes for international students are delivered in English. The reason for European higher education programmes in English are to remove language obstacles for the enrolment of foreign students [26].

Based on the conceptual framework of the present research, engineering students' view on digital entrepreneurship is built on considering such aspects [7], [15] as

- Engineering student's intention to become a digital entrepreneur,

- Use of the host country language, 
- Use of engineering knowledge in digital entrepreneurship.

\section{Methodology OF THE EMPIRICAL STUDY}

The present empirical study was enabled by the research question: What are engineering Master students' views on digital entrepreneurship in a host European country?

The purpose of the empirical study was to analyse the views of engineering Master students on digital entrepreneurship.

The empirical study was carried out in February 2021. The sample was composed of 32 engineering students who were enrolled in the International Master programme "Information and Electrical Engineering" at Hochschule Wismar, Germany. It should be noted that the International Master programme "Information and Electrical Engineering" is taught in English. The host country language, namely German, is provided to the international engineering Master students only during the $2^{\text {nd }}$ semester of the Master studies. As the period of the implementation of the empirical study coincided with the lockdown due to the COVID-19 pandemic, the host country language, namely German, was given to the $2^{\text {nd }}$ semester students online. The content of the German course was not specified.

The engineering Master students were chosen for their participation in the empirical study as master studies are innovation oriented in wide terms. The group of 32 students was heterogenous (the field of study and work, languages, etc):

- 25 students were male, and seven students were female.

- The students were between 20 and 29 years old.

- 31 engineering Master students were originally from India, and one - from Pakistan.

- 21 students indicated a beginner level of German language knowledge.

- The engineering Master students from India were from different regions of India, thereby obtaining different cultural and educational background.

- The students received Bachelor degrees in different fields of engineering: mechanical, electrical, computer, etc.

Hence, Germany was the host country for these international engineering Master students who participated in the online survey.

Furthermore, engineering is the professional field for the international engineering Master students who took part in the survey.

The sample was also multilingual, thereby multicultural:

- Two students spoke two languages,

- 11 students were able to communicate in 3 languages,
- 13 students were able to perform in four languages,

- Three students obtained the knowledge of five languages.

Only three students indicated that they spoke one language, namely English.

The differences in students' cultural and educational experience highlighted the significance of each student's contribution to the study.

The empirical study was of the exploratory nature. The exploratory study was chosen due to the uncertainty in the research field [27]. An exploratory study is characterised by a high degree of flexibility and lack of formal structure [27]. An exploratory study aims to identify the boundaries of the social environment in which the problems, opportunities or situations of interest are likely to reside [27]. The methodology of the exploratory study proceeded [28]

- From Exploration in Phase 1

- Through Analysis in Phase 2

- To Research Question in Phase 3.

The data were collected via an online survey. The online survey was based on the online questionnaire. As the authors support the view that digital entrepreneurship is a supplement or complement to traditional settings [18], the term "entrepreneur", referred to both - entrepreneur and digital entrepreneur, is used in the survey. The online questionnaire was built of such questions:

1. How long have you been staying in the host country?

2. Do you intend to become an entrepreneur?

3. What are your advantages to become an entrepreneur in a host country?

4. What are limitations of becoming an entrepreneur in a host country?

5. Do you intend to become an entrepreneur in your professional field?

The obtained data were visualised. Descriptive statistics were used to feature the sample. Percentage, standard deviation and weighted average were presented to characterize the sample. Afterwards, the data were interpreted and summarised.

\section{RESULTS AND FINDINGS OF THE EMPIRICAL STUDY}

The present part of the paper reveals the results of the online survey and findings of the study.

In regard to Question 1 about the period of students' staying in the host country, the majority of the respondents or 31 students answered that they had been staying in the host country, namely Germany, between 1-3 years. Only one respondent had been staying in the country longer than 3 years. Figure 5 illustrates the percentage and standard deviation of the students' responses. 
Environment. Technology. Resources. Rezekne, Latvia Proceedings of the $13^{\text {th }}$ International Scientific and Practical Conference. Volume 2, 225-231

How long have you been staying in the host country?
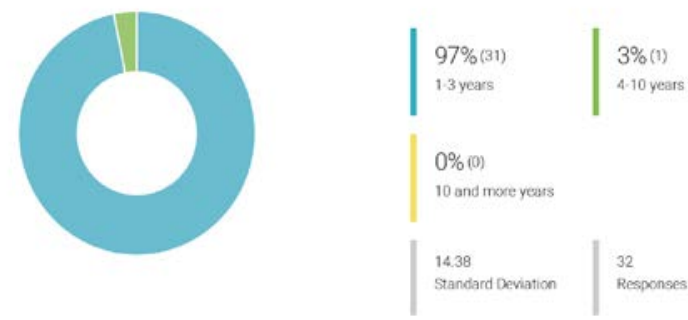

Fig. 5. The respondents’ answers to Question 1 of the survey.

The majority of the engineering Master students expressed their intention to become an entrepreneur as shown in Figure 6. Figure 6 also presents the measurement scale of 10 levels. The 10 levels are ranged between 1 "Extremely poor" and 10 "Extremely good”.

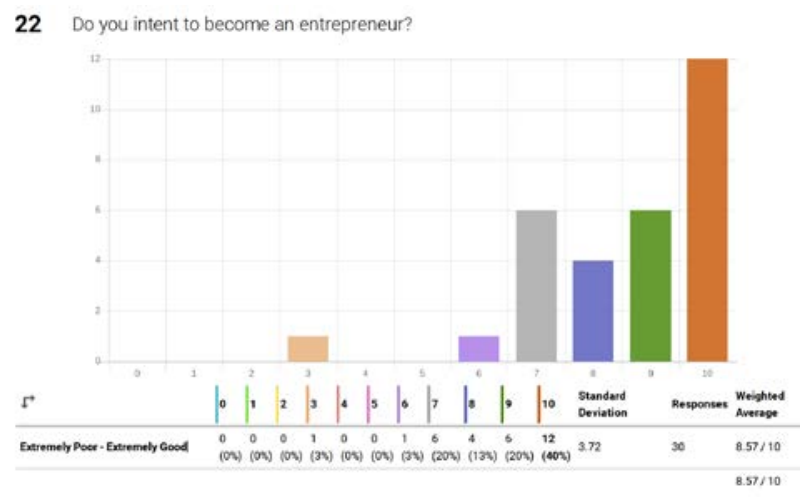

Fig. 6. The respondents' answers to Question 2 of the survey.

The majority of the international engineering Master students determined their advantages to become an entrepreneur in a host country as speaking a couple of languages as presented in Figure 7.

$43 \%$ or nearly the half of the respondents indicated contacts in their origin country as an advantage for entrepreneurship in a host country as depicted in Figure 7.

Two students indicated other advantages they can use for entrepreneurship in a host country as revealed in Figure 7:

- $\quad$ One student considered great opportunities the host country provided to the entrepreneur.

- Another student emphasized continuous trying to improve the host country's language each day.
23
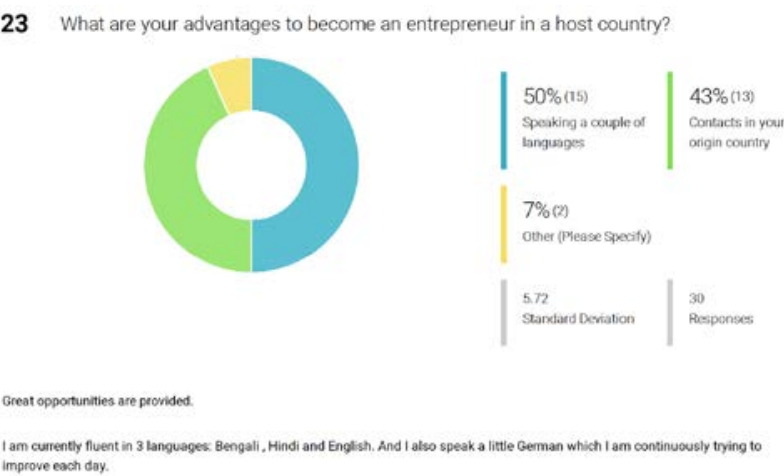

Fig. 7. The respondents' answers to Question 3 of the survey.

On the other hand, the majority of the respondents opined that the host country language is a limitation for becoming an entrepreneur as disclosed in Figure 8. About one third of the respondents pointed that host country rules limit the entrepreneurial intentions of the respondents.

24

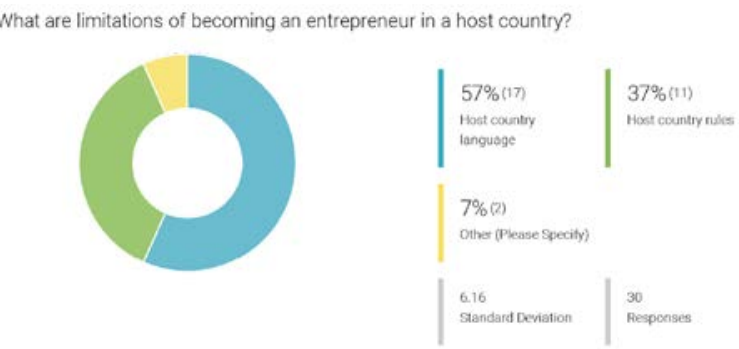

Fig. 8. The respondents' answers to Question 4 of the survey.

The majority of the respondents expressed their intention to become an entrepreneur in their professional field, namely engineering. Figure 9 shows that 24 students or $80 \%$ among the survey respondents answered positively to the question.

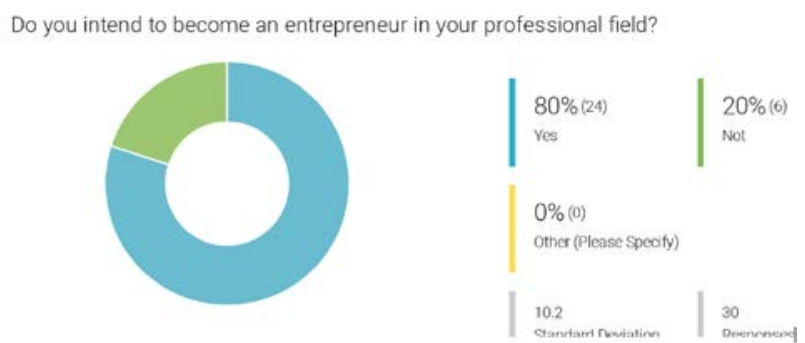

Fig. 9. The respondents' answers to Question 5 of the survey.

The results of the empirical study allow finding out that the majority of the engineering Master students are willing to become entrepreneurs. Another finding is that the majority of the engineering Master students wish to develop their entrepreneurship in their professional field, namely engineering. The survey results show that the respondents were multi-lingual. However, the host country 
language required more efforts from the students with the migrant background to become the students' advantage in entrepreneurship.

Overall, the engineering Master students' view on digital entrepreneurship is positive.

\section{CONCLUSIONS}

The theoretical research results in the conceptual framework for the analysis of engineering students' view on digital entrepreneurship. The conceptual framework is built of such aspects as engineering student's intention to become a digital entrepreneur, use of the host country language, use of engineering knowledge in digital entrepreneurship. The conceptual framework acknowledges that the unity of all the student's language, namely mother tongue, second language, foreign language, host country language, etc [25] is the key concept and issue in an International Master programme.

The empirical study allows drawing the conclusion that international engineering Master students view digital entrepreneurship in a positive way. The survey results show that engineering students' digital entrepreneurship should be centred on their professional field, namely engineering. The online survey also outlined two major factors, namely host country language and host country rules, that limit the opportunities of becoming a digital entrepreneur in a host country.

The implications for engineering education in a host country imply the integration of entrepreneurial culture, namely host country language and host country rules, into engineering education. The focus of the host country language and host country rules should be placed on their use for entrepreneurial purposes. By the entrepreneurial purposes, specific activities that are tied to entrepreneurship are meant. Hence, host country language and host country rules trained within engineering education should be focused on their use for entrepreneurship. Some examples include

- Preparation of a business plan in a host country language,

- Legal regulations for opening the company in a host country,

- Culture of project management in a host country, etc.

It should be noted some cultural differences between international engineering students with the Indian cultural background and their educators with the German cultural background applicable to entrepreneurship have been pointed [29]. The identified differences included [29]

- Use of people names,

- Addressing people,

- Understanding of time management,

- $\quad$ Expression of politeness.

The research has some limitations. A limitation is the link between international engineering student's intention to become a digital entrepreneur, use of the host country language, use of engineering knowledge in digital entrepreneurship. Another limitation is the empirical study conducted by involving only the students of one higher education institution in one country. A limiting parameter also is the participation of only international engineering students in the online survey. Only the respondents at master level of engineering studies took part in the survey that also limits the results of empirical study.

Further theoretical research intends to re-consider the conceptual framework to be applied to the analysis of engineering students' views on digital entrepreneurship. Two major factors, namely host country language and host country rules, that limit the opportunities of becoming a digital entrepreneur in a host country, will be further structured and described as language and culture are the basis of entrepreneurial activities. Training for engineering students' digital entrepreneurship will be further specified. In future, the proposed research will tend to implement empirical studies in other respondents' groups, other institutions and other host countries. The research will broaden the dataset with newly collected qualitative and quantitative data. Implementation of empirical studies will be based on the search for relevant and appropriate methods to analyse engineering students' view on digital entrepreneurship. A comparative research and studies of other countries could be carried out, too.

\section{REFERENCES}

[1] P. Drucker. Innovation \& Entrepreneurship: Practice and Principles. Boston, Butterworth Heinemann, 1985.

[2] F.R. Gunter, “A Simple Model of Entrepreneurship For Principles of Economics Courses”, Journal of Economic Education, Vol. 43, No. 4, 2012, pp. 1-11.

[3] A. Ahrens A., N. Grünwald, O. Bassus, N. Andreeva, J. Zaščerinska, and J. Melnikova. "Impact of Master Programme "Information and Electrical Engineering" for International Students at Hochschule Wismar on Regional Economics: Theoretical Modelling” in В.M. Муров, (отв. редактор); А.Г. Мнацаканян; Р.Ш. Ходжаев,; В.В. Нордин, Scientific Printed Works of the 8th International Scientific Conference Perspectives of Economics of Kaliningrad Region and EU Development, June 22-24, 2017, pp. 6-9. Kaliningrad State Technical University, Kaliningrad, Russian Federation. ISBN 978-5-94826-490-5. УДК 332.1(470.26)(06), 2017, pp. 6-9.

[4] Joshi, Manoj. The Connection between Entrepreneurship \& Innovation (June 27, 2017). Available at SSRN: http://dx.doi.org/10.2139/ssrn.2993091. [Accessed March 1, 2021].

[5] Kaushik C Akiwatkar and Parul P. Bhati, “The Role of Government Policy in Fostering Entrepreneurship and Innovation Culture in Gujarat State”, Proceedings of 9th International Conference on Engineering and Business Education (ICEBE) \& 6th International Conference on Innovation and Entrepreneurship (ICIE) on Fostering Global Knowledge Economy through Innovative and Creative Engineering \& Management Studies, 24-26 February 2016, Volume: 1, pp. 1-6. Published by Centre for Global Business Studies (CGBS) Gujarat Technological University (GTU) Ahmedabad, India. ISBN: 978-3-942100-43-4.

[6] O. Bassus, A. Ahrens, and J. Zaščerinska, "Entrepreneurship Education in Engineering Education: Focus on Students' Needs”, in Proceedings of the 7th International Conference on Engineering and Business Education 13 - 14 October 2014, pp. 69-76. Published by University of Wismar, Germany. ISBN 978-3924100-05-2.

[7] Virginia Barba-Sánchez and Carlos Atienza-Sahuquillo, Entrepreneurial intention among engineering students: The role of entrepreneurship education, European Research on Management 
and Business Economics, Volume 24, Issue 1, 2018, Pages 53-61, ISSN 2444-8834, https://doi.org/10.1016/j.iedeen.2017.04.001.

[8] L. Aḷeksejeva, M. Zaščerinskis, J. Zaščerinska, and N. Andreeva. "Engineering Students as Entrepreneurs: Context Analysis", in Proceedings of 15th Students' and Educators' Scientific Practical Conference Economics Development: Challenges and Solutions, Rezekne Higher Education Institution, Rezekne, Latvia. 30 May 2013, pp. 6-16. Rēzekne, Latvia: Rēzeknes Augstskolas Izdevniecība 2013, ISBN 978-9984-44-134-4.

[9] O. Bassus, J. Zaščerinska, and A. Ahrens. "From Enterprise 2.0 to 3.0: Challenges in Engineering and Business Education”, in Bassus, O.; Ahrens, A.; Lange, C. (Ed.), Information and Communication Technologies in Engineering and Business, 2011, pp. 79-99. Berlin: Mensch \& Buch, 2011, Germany. ISBN: 978-386664-901-9.

[10] M. Zaščerinskis, J. Zaščerinska, and R. Hariharan. "Engineering Students' Attitude to E-Business Application”, in Proceedings of the 18th International Scientific Practical Conference of Students "Human. Environment. Technology.” Rezekne Higher Education Institution, Rezekne, Latvia, 23 April 2014, pp. 344-354. Rēzekne, Latvia: Rēzeknes Augstskolas Izdevniecība 2014, ISBN 978-998444-153-5.

[11] Andreas Kuckertz, Leif Brändle, Anja Gaudig, Sebastian Hinderer, Carlos Arturo Morales Reyes, Alicia Prochotta, Kathrin M. Steinbrink, Elisabeth S.C. Berger, Startups in times of crisis - A rapid response to the COVID-19 pandemic, Journal of Business Venturing Insights, Volume 13, 2020, e00169, ISSN 2352-6734, https://doi.org/10.1016/j.jbvi.2020.e00169.

[12] C. Duan, B. Kotey, and K. Sandhu. "Digital Entrepreneurship for Immigrants: Motivations, Strategies, Ecosystems, and Performance” in Kamaljeet Sandhu (University of New England, Australia) (Ed), Leadership, Management, and Adoption Techniques for Digital Service Innovation. IGI Global, 2020. DOI: 10.4018/978-1-7998-2799-3.ch009

[13] M. Zhou. "Revisiting ethnic entrepreneurship: Convergencies, controversies, and concep- tual advancements", International Migration Review, 38: 1040-1074, Fall 2004.

[14] L. Pieroni, G. d'Agostino, and D. Lanari, D. "The effects of language skills on immigrant employment and wages in Italy”. MPRA Paper No. 91725, 2019.

[15] A. Ahrens, and J. Zaščerinska, "Immigrants‘ Use of Language for Professional Purposes in a Host Country: Implications for Adult Education”. Society. Integration. Education Proceedings of the International Scientific Conference. Volume V, May 22nd -23rd, 2020. pp. 335-345. http://dx.doi.org/10.17770/sie2020vol5.4860.

[16] C. Duan, B. Kotey, and K. Sandhu. "Transnational immigrant entrepreneurship: effects of home-country entrepreneurial ecosystem factors", International Journal of Entrepreneurial Behavior \& Research, Vol. ahead-of-print No. ahead-of-print, 2020. https://doi.org/10.1108/IJEBR-05-2020-0300

[17] European Commission. Digital Transformation of European Industry and Enterprises: A report of the Strategic Policy Forum on Digital Entrepreneurship, 2015. Available: http://ec.europa.eu/DocsRoom/documents/9462/attachments/1/tra nslations/en/renditions/native. [Accessed: March, 2, 2021].

[18] J. Melnikova, V. Jurgaityte, J. Zaščerinska, L. Aleksejeva, A. Leete, H. Koppel, I. Rohdin, A. Olsson. "Immigrants and Asylum Seekers’ Digital Entrepreneurship Competence: Evaluation of the Theoretical Framework", in Claudiu Vasile Kifor, Norbert Grünwald and Lucian Lobont (Eds), Proceedings of the 9th Balkan Region Conference on Engineering and Business Education (BRCEBE) \& 12th International Conference on Engineering and Business Education (ICEBE) Sibiu, România, 16 - 19 October 2019, pp. 408-416. DOI: https://doi.org/10.2478/cplbu-2020-0047.

[19] J. Zaščerinska. "Professional Environment for Teacher Professional Development” in Proceedings of 5th International scientific conference Theory for Practice in the Education of Contemporary Society of Riga Teacher Training and Educational Management Academy, 25 - 27 March 2010, pp. 396-402. Riga, Latvia. ISBN 978-9934-8060-5-6.

[20] E. Maslo. “Transformative Learning Space for Life-Long Foreign Languages Learning” in International Nordic-Baltic Region Conference of FIPLV Innovations in Language Teaching and Learning in the Multicultural Context 15-16th June, 2007, Riga, Latvia, p. 38-46.

[21] A. Faustmann, Magdalena Filipova-Rivers, and Isabella Skrivanek. "Identifying common issues and challenges of Migrant Entrepreneurship Support and the role of entrepreneurial skills" Report on the 1ST Thematic Network Forum. Krems, Austria | June $2018 . \quad$ https://migrantacceleration.eu/media/D1.1-TNF1Report_final.pdf. [Accessed: March 2, 1998].

[22] Azemina Masovic. Socio-Cultural Factors and Their Impact on the Performance of Multinational Companies. ECOFORUM [Volume 7, Issue 1(14), 2018].

[23] A. Ahrens, J. Zaščerinska, R. Hariharan, and N. Andreeva "Educators' Opinion on Webinars in Higher Education" in Proceedings of the International Scientifical Conference Society, Integration, Education, Volume 1 Higher Education Pedagogy, May, 27th-28th, 2016, pp. 15-27. - Rezekne: Rezeknes Academy of Technologies, 2016. p. 564. ISSN 2256-0629. DOI: http://dx.doi.org/10.17770/sie2016vol1.1488.

[24] A. Ahrens, M. Foerster, J. Zaščerinska, I. Wasser. ”European Accreditation Agency's View on Kazakhstan's Engineering and Information Technology Higher Education" in SOCIETY. INTEGRATION. EDUCATION Proceedings of the International Scientific Conference. Volume V, May 22nd -23rd, 2020. pp. 1525. ISSN: 2256-0629. http://dx.doi.org/10.17770/sie2020vol1.4861.

[25] J. Zaščerinska, J. Development of Students' Communicative Competence within English for Academic Purposes Studies. Verlag: Mensch \& Buch. 2013, 202 pp. ISBN-13: 978-3-86387359-2.

[26] B. Wächter and F. Maiworm (Eds.). English-Taught Programmes in European Higher Education. The State of Play in 2014. Bonn, Germany: Lemmens.

[27] A. Ahrens, N. Gruenwald, O. Bassus, J. Zaščerinska, and J. Melnikova. "Master Programme "Information and Electrical Engineering” for International Students at Hochschule Wismar: Theoretical Framework" in Claudiu Vasile Kifor, Norbert Gruenwald, Lucian Lobont (Eds), Conference Proceedings of 8th Balkan Region Conference on Engineering and Business Education (BRCEBE) and 10th International Conference on Engineering and Business Education (ICEBE) "Creating a mindset for growth and socio-economic development” 19 - 22 October 2017, Lucian Blaga University of Sibiu, Romania, pp. 175-182. Published in Romania by Lucian Blaga University of Sibiu. De Gruyter Online. DOI: https://doi.org/10.1515/cplbu-2017-0023.

[28] A. Ahrens, O. Bassus, and J. Zascerinska. "Bi-professional Curriculum in Higher Education: Context Analysis” in Proceedings of 6th ICEBE International Conference on Engineeirng and Business Education Innovation, Entrepreneurship and Sustainability, Windhoek, Namibia, 7 - 10 October 2013, pp. 101107. Published by University of Wismar, Germany, 2017.

N. Gruenwald, A. Ahrens, J. Zaščerinska, J. Melnikova, and N. Andreeva.” Socio-Cultural Adaptation of International Students of Master Programme "Information and Electrical Engineering" at Hochschule Wismar” in Norbert Grünwald, Małgorzata Zakrzewska (Editors), Proceedings of the 5th International Scientific Conference on "Modern Economics”. 14-16 May 2018. Vigo, Spain, pp. 33-39. Published by University of Wismar, Germany. ISBN: 978-3-942100-56-4. 